\title{
THE BISULPHITE BINDING POWER OF THE BLOOD IN HEALTH AND IN DISEASE, WITH SPECIAL REFERENCE TO VITAMIN $B_{1}$ DEFICIENCY ${ }^{1}$
}

\author{
By F. H. L. TAYLOR, SOMA WEISS AND ROBERT W. WILKINS \\ (From the Thorndike Memorial Laboratory, Second and Fourth Medical Services (Harvard), \\ Boston City Hospital, and the Department of Medicine, Harvard Medical Schod, \\ Boston)
}

(Received for publication May 4, 1937)

There is increasing evidence that the biological function of vitamin $B_{1}$ is concerned with oxidative processes in the living organism. In studies of oxygen utilization by manometric methods, Peters and his coworkers $(1,2)$ have shown that there is increased oxygen uptake by deficient brain and kidney tissues in vitro following the addition of vitamin $B_{1}$. In the same laboratory Thompson and Johnson $(3,4)$ found increased amounts of carbonyl compounds in the blood of $B_{1}$ avitaminotic pigeons and rats. Clinical confirmation has recently been given these experimental findings by Platt and $\mathrm{Lu}$ (5), who reported marked increases in the carbonyl compounds in the blood of patients with acute beriberi in the Orient.

These authors measured the carbonyl compounds by means of the bisulphite binding power of the blood. Pyruvic acid has received most attention, chiefly through the emphasis given to it by Peters et al. (2). Thompson and Johnson concluded that the major portion of the increase in bisulphite binding substances (B.B.S.) in the blood of pigeons and rats severely deficient in vitamin $B_{1}$ was due to pyruvic acid. On the other hand, Sherman and Elvehjem (6) found no increase in the B.B.S. in the blood of chickens deficient in vitamin $B_{1}$, but did find that these birds, in contrast to normal birds, showed a sharp rise in blood B.B.S. after the intravenous injection of sodium pyruvate. Platt and $\mathrm{Lu}$ in a recent report (7) state that the increases in B.B.S. in the blood of fulminating cases of beriberi are due mainly to pyruvic acid.

For 2 years an investigation has been in progress in this laboratory on patients with symptoms and signs of vitamin $\mathrm{B}_{1}$ deficiency closely resembling those seen in oriental "wet" beriberi ( 8 ,

1 This investigation was aided in part by a grant from the Josiah Macy, Jr. Foundation.
9). The present study of the B.B.S. in the blood was undertaken in order (1) to throw further light on the relationship of these cases of vitamin $\mathrm{B}_{1}$ deficiency to those reported in other parts of the world; (2) to relate the B.B.S. in the blood to clinical and laboratory findings in various medical diseases in order to determine the factors which influence the B.B.S.; and (3) to ascertain the diagnostic and prognostic value of measurements of the B.B.S. in the blood.

\section{SELECTION OF CASES}

The present communication reports the findings in a group of 174 persons, consisting of 30 normal subjects and 144 patients. The control subjects were members of the hospital staff and were free from any evidence of disturbed metabolism, infection or vitamin deficiency. The patients were chosen from the medical wards of this hospital and were predominantly persons with metabolic disturbances, including vitamin $\mathrm{B}_{1}$ deficiency. An additional group of patients was selected in order to determine the rôle of certain diseases which frequently complicate vitamin $B_{1}$ deficiency, such as alcoholism.

The distribution of the patients is shown in Table I. In assigning a patient to the group with

TABLE I

Distribution of cases

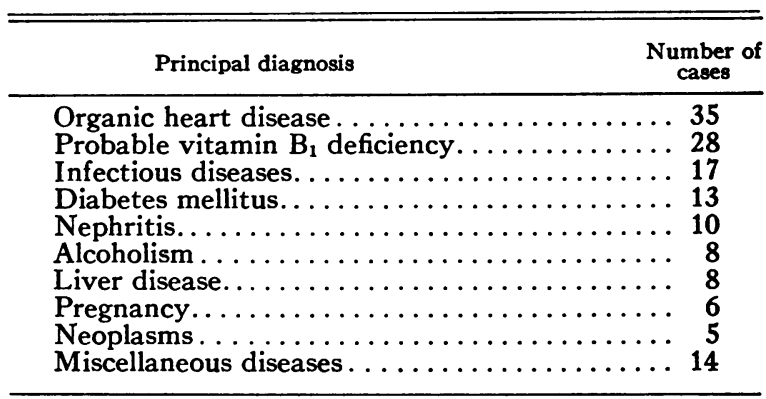


probable vitamin $B_{1}$ deficiency, the presence of one or more of the following clinical criteria was required in addition to a history of a diet grossly deficient in vitamin $B_{1}$ and improvement after vitamin $B_{1}$ therapy: peripheral polyneuritis, pellagra, Korsakoff type of psychosis, congestive failure of the circulation without any other adequate explanation than vitamin $B_{1}$ deficiency, or polyavitaminosis with malnutrition. It is appreciated that such a classification is not rigidly accurate as the criteria used depend largely on the interpretation of history and physical findings. Furthermore, it is recognized that the patients in this group usually suffered from a deficiency not only of $B_{1}$ but also of the other fractions of the vitamin B complex as well as a deficiency of other vitamins. Because of the frequent association in this hospital of chronic alcoholism with avitaminosis, a relatively large number of alcoholic patients were included.

Certain patients were treated during the period of observation with the specific therapy required for their condition. In such cases repeated observations were usually made both before treatment (Part A of the tables) and after treatment (Part B). Attention is called to these cases by means of an asterisk. Because of lack of space only one series of observations before and one series after treatment are presented.

\section{METHODS}

Blood was taken from patients fasting and at rest and delivered into bottles containing dry potassium oxalate. Duplicate samples were analyzed without delay.

Bisulphite binding power. Slight modifications were made in the method of Clift and Cook (10) in order to adapt it to whole blood determinations. Five ml. of oxalated blood were precipitated with $20 \mathrm{ml}$. of 10 per cent trichloracetic acid, allowed to stand 30 minutes and centrifuged. The clear supernatant fluid was removed from the precipitated protein. Determinations were made immediately, although it was found that the protein-free filtrate might be kept in the ice chest overnight without change in bisulphite binding power.

Five $\mathrm{ml}$. aliquots of the supernatant fluid were adjusted to $\mathrm{pH} 2$ by the addition of $1.5 \mathrm{ml}$. of normal sodium hydroxide, and allowed to react for at least 15 minutes with $0.2 \mathrm{ml}$. of saturated sodium bisulphite solution. Accurate control of the $\mathrm{pH}$ is not essential, but the alkalinity should not be permitted to rise above $\mathrm{pH} 4$.

The solution was then diluted with $25 \mathrm{ml}$. of distilled water, $2 \mathrm{ml}$. of freshly prepared 1 per cent starch solu- tion added, and the excess of bisulphite titrated out, first using normal and N/10 iodine solutions and finally adjusting the end point with N/200 iodine and N/100 thiosulphate solutions. The volume at the end of this part of the procedure should be approximately $65 \mathrm{ml}$. The preliminary dilution prevents the formation of a yellowish compound, probably an iodate-iodine combination, which may cause high results. At $\mathrm{pH} 2$ the reactions of iodine and thiosulphate solutions proceed more slowly than when the solutions are acid with $6 \mathrm{~N}$ hydrochloric acid, as is usual in iodimetry. For this reason the titration of excess bisulphite must be done slowly; otherwise some thiosulphate remains unchanged and increases the bound bisulphite titer.

The bound bisulphite is then released by the addition of 2 grams of solid disodium phosphate $\left(\mathrm{Na}_{2} \mathrm{HPO}_{4} \cdot 12\right.$ $\mathrm{H}_{2} \mathrm{O}$ ), mixing for 5 minutes by rotation to avoid aeration. The released bisulphite is then titrated with $\mathrm{N} / 200$ iodine solution. The end point chosen is that at which a definite blue color persists for 30 seconds. Blanks are run on the reagents and these may be used as reference solutions for the end point. The bisulphite binding power is expressed as milligrams of pyruvic acid, using the equation: $1 \mathrm{ml}$. $\mathrm{N} / 200$ iodine solution $=0.22 \mathrm{mgm}$. pyruvic acid.

The $\mathrm{N} / 200$ iodine solution should be standardized once a week, and when many determinations are being run the burette should be refilled with fresh iodine solution every hour.

Blood sugar and nonprotein nitrogen were determined by the method of Folin (11), plasma proteins by a modification of the Howe procedure $(12,13)$ and carbon dioxide capacity by the method of Van Slyke (14). Urines were examined for acetone and diacetic acid by the routine clinical tests, and in addition for pyruvic acid by a modification (15) of the Simon-Piaux method.

\section{RESULTS}

The bisulphite binding power of the blood in the normal subjects ranged from 3.7 to $5.8 \mathrm{mgm}$. per $100 \mathrm{ml}$. of whole blood, with an average of $4.7 \mathrm{mgm}$. It has been arbitrarily decided to consider all values above $6 \mathrm{mgm}$. per $100 \mathrm{ml}$. as increased, and values below $3.5 \mathrm{mgm}$. per $100 \mathrm{ml}$. as decreased.

Table II gives the diseases in which an increase in the B.B.S. in the blood was found, and the incidence of increased B.B.S. in each condition. In addition to these diseases, the bisulphite binding power of the blood was found increased in seven other conditions, with only one example of each. This group included chronic vomiting, therapeutically induced ketosis in epilepsy, bichloride poisoning with nitrogen retention, acute hepatitis 
TABLE II

Diseases with increased B.B.S. in the blood

\begin{tabular}{|c|c|c|c|c|c|}
\hline \multirow{2}{*}{ Diagnosis } & \multirow{2}{*}{$\begin{array}{l}\text { Number } \\
\text { of cases }\end{array}$} & \multirow{2}{*}{$\begin{array}{c}\text { Number } \\
\text { with } \\
\text { elevated } \\
\text { B.B.S. }\end{array}$} & \multicolumn{3}{|c|}{ B.B.S. (as pyruvic acid) } \\
\hline & & & Minimum & Marimum & Average \\
\hline $\begin{array}{l}\text { Organic heart disease (decompensated) } \ldots \ldots \ldots \ldots \\
\text { Vitamin } \mathbf{B}_{\mathbf{1}} \text { deficiency (untreated) } \ldots \ldots \ldots \ldots \ldots \ldots \\
\text { Infectious diseases (febrile) } \ldots \ldots \ldots \ldots \ldots \ldots \ldots \ldots \ldots \ldots \\
\text { Diabetes with acidosis } \ldots \ldots \ldots \ldots \ldots \ldots \ldots \ldots \ldots \ldots \ldots \ldots \\
\text { Nephrosclerosis } \ldots \ldots \ldots \ldots \ldots \ldots \ldots \ldots \ldots \ldots\end{array}$ & $\begin{array}{r}19 \\
23 \\
9 \\
7 \\
4\end{array}$ & $\begin{array}{r}10 \\
18 \\
6 \\
7 \\
2\end{array}$ & $\begin{array}{c}\text { mgm. per } 100 \mathrm{ml} . \\
4.2 \\
4.6 \\
3.7 \\
6.8 \\
3.7\end{array}$ & $\begin{array}{c}\text { mgm. per } 100 \mathrm{ml} . \\
8.2 \\
51.9 \\
9.2 \\
109.2 \\
7.8\end{array}$ & $\begin{array}{c}\text { mgm. per } 100 \mathrm{ml} . \\
6.2 \\
12.1 \\
6.3 \\
38.6 \\
5.7\end{array}$ \\
\hline
\end{tabular}

with fever, Hodgkin's disease complicated by chronic nephrosclerosis, diabetes mellitus complicated by arteriosclerosis, pericarditis and nephritis, and pancreatitis complicated by vomiting, myocarditis and nephritis.

Table III presents the findings in conditions in which no increase in the B.B.S. in the blood oc-
The relationship of the bisulphite binding power of the blood to vitamin $B_{1}$ deficiency and to alcoholism

Table IV-A presents the data on 23 cases of probable vitamin $B_{1}$ deficiency observed before treatment. The cases are arranged in order of severity as determined by clinical observation.

TABLE III

Conditions with no increase in B.B.S. in the blood

\begin{tabular}{|c|c|c|c|c|}
\hline & $\begin{array}{c}\text { Number of } \\
\text { cases }\end{array}$ & Minimum & Maximum & Average \\
\hline
\end{tabular}

* This group includes certain cases appearing in Table II which, subsequent to treatment, showed no elevation of B.B.S. in the blood.

curred. In addition, the B.B.S. was not increased in 1 case each of hyperthyroidism, starvation, nephrosis, and hypoproteinemia associated with chronic colitis.

From such a selection of cases no conclusions can be drawn concerning the incidence of increased B.B.S. in medical diseases. The frequent association of certain of the diseases studied with an increase in the B.B.S. in the blood, nevertheless, requires further scrutiny.
Cases 1 to 8 , inclusive, were regarded as severe, if not "fulminating," and were characterized by marked congestive failure of the circulation with massive edema, as well as by varying degrees of peripheral neuritis and psychosis. It will be seen that there was no uniform relationship between the clinical severity of the disease and the amount of the B.B.S. in the blood. Nevertheless 17 , or 74 per cent, of the untreated group had an increase in the B.B.S. This is in striking contrast 
TABLE IV

Cases with vitamin $B_{1}$ deficiency

(Arranged in order of severity of symptoms)

\begin{tabular}{|c|c|c|c|c|c|c|c|c|c|c|c|c|}
\hline \multirow{2}{*}{$\begin{array}{c}\text { Case } \\
\text { num- } \\
\text { ber }\end{array}$} & \multirow{2}{*}{ Sex } & \multirow{2}{*}{ Age } & \multirow{2}{*}{$\begin{array}{l}\text { Time of } \\
\text { test } \\
\text { (day in } \\
\text { hospi- } \\
\text { tal) }\end{array}$} & \multirow{2}{*}{$\begin{array}{l}\text { B.B.S. } \\
\text { (as pyru- } \\
\text { vic acid) }\end{array}$} & \multirow{2}{*}{$\begin{array}{c}\text { Non- } \\
\text { protein } \\
\text { nitrogen }\end{array}$} & \multirow{2}{*}{$\begin{array}{c}\mathrm{CO}_{2} \\
\text { capac- } \\
\text { ity }\end{array}$} & \multirow{2}{*}{$\begin{array}{l}\text { Blood } \\
\text { sugar }\end{array}$} & \multicolumn{4}{|c|}{ Urine analysis } & \multirow{2}{*}{ Course } \\
\hline & & & & & & & & Acetone & $\begin{array}{c}\text { Di- } \\
\text { acetic }\end{array}$ & $\begin{array}{l}\text { Py: } \\
\text { ruvic }\end{array}$ & Sugar & \\
\hline & & years & & $\begin{array}{l}\text { mgm. per } \\
100 \mathrm{ml} .\end{array}$ & mgm. per & $\begin{array}{l}\text { volumes } \\
\text { per cent }\end{array}$ & $\begin{array}{l}\text { mgm. per } \\
100 \mathrm{ml} .\end{array}$ & & & & & \\
\hline
\end{tabular}

A. UNTREATED CASES

\begin{tabular}{|c|c|c|c|c|c|c|c|c|c|c|c|c|}
\hline $\begin{array}{r}1 \\
2 \\
3 \\
4 \\
5 \\
6 \\
7 \\
8 \\
9 \\
9 \\
10 \\
11 \\
12 \\
13 \\
14 \\
15 \\
16 \\
17 \\
18 \\
19 \\
20 \\
21 \\
22 \\
23\end{array}$ & $\begin{array}{l}\text { M. } \\
\text { M. } \\
\mathbf{M} . \\
\mathbf{M} . \\
\mathbf{F} . \\
\text { M. } \\
\text { M. } \\
\mathbf{M} . \\
\mathbf{F} . \\
\mathbf{F} . \\
\mathbf{M} . \\
\mathbf{M} . \\
\mathbf{M} . \\
\mathbf{M} . \\
\mathbf{M} . \\
\mathbf{F} \\
\mathbf{M} . \\
\mathbf{M} . \\
\mathbf{M} . \\
\mathbf{M} . \\
\mathbf{M} . \\
\mathbf{M} . \\
\mathbf{M} .\end{array}$ & $\begin{array}{l}43 \\
49 \\
35 \\
60 \\
52 \\
69 \\
42 \\
69 \\
55 \\
38 \\
43 \\
48 \\
42 \\
51 \\
60 \\
29 \\
47 \\
36 \\
46 \\
36 \\
37 \\
56 \\
41\end{array}$ & $\begin{array}{r}1 \\
4 \\
3 \\
5 \\
16 \\
4 \\
6 \\
3 \\
3 \\
3 \\
7 \\
4 \\
5 \\
4 \\
1 \\
3 \\
2 \\
3 \\
2 \\
2 \\
2 \\
2 \\
6\end{array}$ & $\begin{array}{r}13.9 \\
9.6 \\
14.6 \\
8.3 \\
7.0 \\
2.8 \\
4.6 \\
7.3 \\
8.4 \\
7.1 \\
4.0 \\
6.3 \\
8.1 \\
5.8 \\
13.7 \\
51.9 \\
50.8 \\
7.9 \\
15.1 \\
11.0 \\
7.3 \\
5.1 \\
4.9\end{array}$ & $\begin{array}{l}80 \\
82 \\
30 \dagger \\
32 \dagger \\
28 \dagger \\
26 \dagger \\
32 \\
23 \\
38 \dagger \\
32 \\
33 \\
39 \dagger \\
44 \\
43 \\
19 \\
45 \\
36 \\
37 \\
23 \dagger \\
22 \\
50 \\
25\end{array}$ & $\begin{array}{l}63 \\
61 \\
\\
57 \\
59 \\
\\
61 \\
70 \\
65 \\
52\end{array}$ & $\begin{array}{c}93 \\
\\
\\
109 \\
80 \dagger \\
232 \\
99 \\
124 \\
153\end{array}$ & $\begin{array}{c}0 \\
0 \\
++ \\
+ \\
0 \\
0 \\
0 \\
0 \\
0 \\
0 \\
0 \\
0 \\
0 \\
0 \\
++ \\
\pm \\
0 \\
0 \\
++++ \\
++++ \\
+++ \\
0\end{array}$ & $\begin{array}{l}0 \\
0 \\
0 \\
0 \\
0 \\
0\end{array}$ & $\begin{array}{l}0 \\
0 \\
+ \\
+ \\
+ \\
0 \\
+ \\
0 \\
+\end{array}$ & $\begin{array}{c}0 \\
0 \\
0 \\
0 \\
0 \\
0 \\
0 \\
0 \\
+ \\
+ \\
0 \\
0 \\
0 \\
0 \\
\text { Trace } \\
0 \\
0 \\
0 \\
+ \\
\text { Trace } \\
\text { Trace } \\
0\end{array}$ & $\begin{array}{l}\text { Died } \\
\text { Improved } \\
\text { Improved } \\
\text { Improved } \\
\text { Died } \\
\text { Improved } \\
\text { Died } \\
\text { Improved } \\
\text { Died } \\
\text { Improved } \\
\text { Improved } \\
\text { Improved } \\
\text { Improved } \\
\text { Improved } \\
\text { Improved } \\
\text { Improved } \\
\text { Improved } \\
\text { Improved } \\
\text { Improved } \\
\text { Improved } \\
\text { Improved } \\
\text { Improved } \\
\text { Improved }\end{array}$ \\
\hline
\end{tabular}

B. TREATED CASES

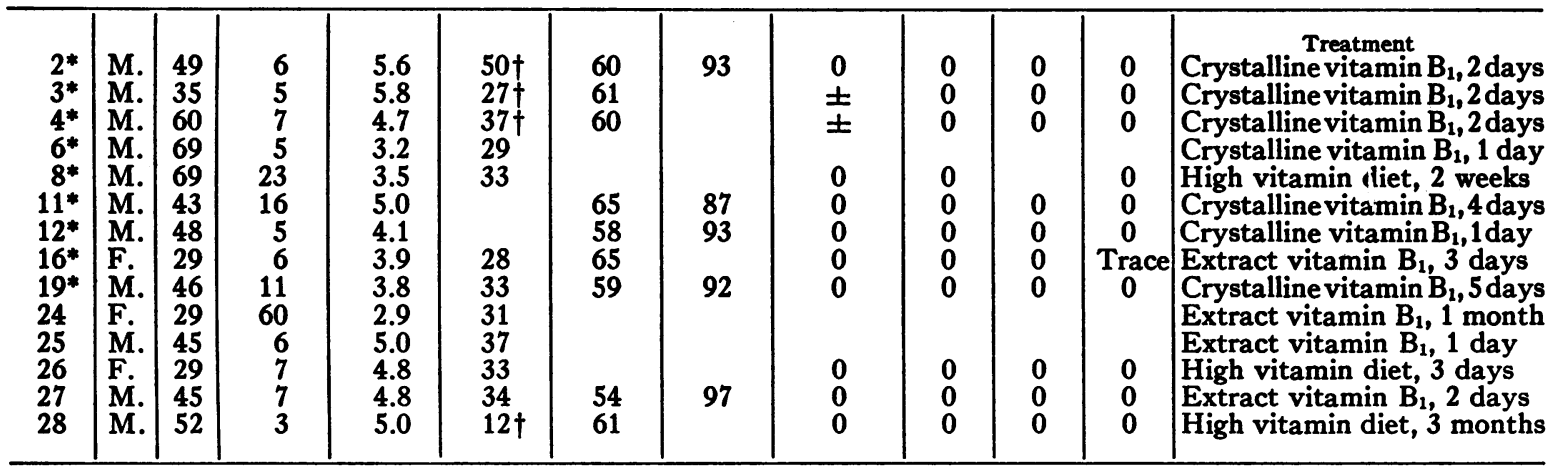
made.

* These cases appear in section $A$ of this table. The other cases received treatment before any observations were $\dagger$ Determination on plasma.

to a group of the same and similar patients who after vitamin $B_{1}$ therapy (Table IV-B) had consistently normal B.B.S. in the blood.

Because all but one of the deficient patients (Case 9) were also alcoholic, it was necessary to determine the effect, if any, of alcohol per se on the B.B.S. A control group of 8 cases was selected, 4 with acute alcoholism (in coma) and 4 with chronic alcoholism without signs or symptoms of vitamin deficiency and without manifestations of acute alcoholic intoxication (Table V). In no instance was there an increase in the B.B.S. in the blood. This finding and the fact that the cases of chronic alcoholism and vitamin $B_{1}$ defi- 
ciency showed a prompt return of the B.B.S. to normal after crystalline vitamin $B_{1}$ therapy ( $\mathrm{Ta}$ ble IV-B) indicate that the increase in the B.B.S. in these cases is related to the vitamin deficiency and not directly to the chemical or physiological effectsmof alcohol.

The increase in the B.B.S. in the blood was not the only evidence of abnormal metabolism in the cases of vitamin $B_{1}$ deficiency. The fasting blood sugar was increased in 4 cases (Table IV-A), but returned to normal after treatment with crystalline vitamin $B_{1}$ or adequate diet. Moreover, sugar, acetone, diacetic acid and pyruvic acid were found in the urine of several patients before treatment, but were rarely present after vitamin therapy.

TABLE V

Cases with alcoholism without vitamin $B_{1}$ deficiency

\begin{tabular}{|c|c|c|c|c|c|c|}
\hline Case number & Sex & Age & $\begin{array}{l}\text { Time of test } \\
\text { (day in } \\
\text { hospital) }\end{array}$ & Type & B.B.S. (as pyruvic acid) & Nonprotein nitrogen \\
\hline $\begin{array}{l}29 \\
30 \\
31 \\
32 \\
33 \\
34 \\
35 \\
36\end{array}$ & $\begin{array}{l}\mathbf{M} . \\
\mathbf{M} \\
\mathbf{M} \\
\mathbf{M} \\
\mathbf{M} \\
\mathbf{M} \\
\mathbf{M} . \\
\mathbf{M}\end{array}$ & $\begin{array}{c}\text { years } \\
32 \\
32 \\
30 \\
35 \\
45 \\
38 \\
51 \\
67\end{array}$ & $\begin{array}{l}1 \\
1 \\
1 \\
1 \\
1 \\
3 \\
3 \\
3 \\
8\end{array}$ & $\begin{array}{l}\text { Acute } \\
\text { Acute } \\
\text { Acute } \\
\text { Acute } \\
\text { Chronic } \\
\text { Chronic } \\
\text { Chronic } \\
\text { Chronic }\end{array}$ & $\begin{array}{c}\text { mgm. per } 100 \mathrm{ml} . \\
4.2 \\
5.3 \\
5.2 \\
4.0 \\
4.7 \\
4.8 \\
4.9 \\
5.0\end{array}$ & mgm. per $100 \mathrm{ml}$ \\
\hline
\end{tabular}

TABLE VI

Cases with diabetes mellitus

(Arranged in order of severity of symptoms)

\begin{tabular}{|c|c|c|c|c|c|c|c|c|c|c|c|}
\hline \multirow{2}{*}{$\begin{array}{c}\text { Case } \\
\text { num- } \\
\text { ber }\end{array}$} & \multirow{2}{*}{ Sex } & \multirow{2}{*}{ Age } & \multirow{2}{*}{$\begin{array}{l}\text { Time of } \\
\text { test (day in } \\
\text { hospital) }\end{array}$} & \multirow{2}{*}{$\begin{array}{l}\text { B.B.S. } \\
\text { (as pyruvic } \\
\text { acid) }\end{array}$} & \multirow{2}{*}{$\begin{array}{c}\text { Non- } \\
\text { protein } \\
\text { nitrogen }\end{array}$} & \multirow{2}{*}{$\mathrm{CO}_{2}$ capacity } & \multirow{2}{*}{ Blood sugar } & \multicolumn{4}{|c|}{ Urine analysis } \\
\hline & & & & & & & & Acetone & Diacetic & Pyruvic & Sugar \\
\hline & . & years & & $\begin{array}{l}\text { mgm. per } \\
100 \text { ml. }\end{array}$ & $\begin{array}{l}\text { mgm. per } \\
100 \text { ml. }\end{array}$ & $\begin{array}{l}\text { volumes } \\
\text { per cent }\end{array}$ & $\begin{array}{l}\text { mgm. per } \\
100 \mathrm{mb} .\end{array}$ & & & & \\
\hline
\end{tabular}

A. UNREgulated CASES

\begin{tabular}{c|c|c|c|c|c|c|c|c|c|c|c}
\hline 36 & F. & 60 & 1 & 109.2 & 64 & 22 & 471 & ++++ & Trace & + & ++ \\
37 & F. & 14 & 1 & 63.9 & & 29 & 187 & ++++ & Trace & 0 & ++ \\
38 & F. & 17 & 2 & 37.7 & 77 & 23 & 293 & + & 0 & & +++ \\
39 & M. & 34 & 1 & 33.2 & 24 & 23 & 292 & ++++ & 0 & + \\
40 & F. & 50 & 1 & 11.0 & 46 & 60 & 274 & +++ \\
41 & F. & 55 & 1 & 8.4 & 46 & & 305 & +++ & Trace & + & +++ \\
42 & F. & 65 & 2 & 6.8 & 46 & & 286 & 0 & & & + \\
\hline
\end{tabular}

B. REgulated CASES

\begin{tabular}{|c|c|c|c|c|c|c|c|c|c|c|c|}
\hline $\begin{array}{l}37^{*} \\
38^{*} \\
39^{*} \\
41^{*} \\
43 \\
44 \\
45 \\
46 \\
47 \\
48\end{array}$ & $\begin{array}{l}\text { F. } \\
\text { F. } \\
\text { M. } \\
\text { F. } \\
\text { F. } \\
\text { F. } \\
\text { F. } \\
\text { M. } \\
\text { F. } \\
\text { M. }\end{array}$ & $\begin{array}{l}14 \\
17 \\
34 \\
55 \\
53 \\
56 \\
52 \\
14 \\
39 \\
51\end{array}$ & $\begin{array}{r}35 \\
13 \\
16 \\
7 \\
34 \\
20 \\
2 \\
12 \\
5 \\
2\end{array}$ & $\begin{array}{l}4.3 \\
4.9 \\
5.0 \\
5.2 \\
5.1 \\
5.6 \\
5.3 \\
4.4 \\
3.1 \\
5.8\end{array}$ & $\begin{array}{l}30 \\
29 \\
\\
31 \\
31 \\
39 \\
30 \\
16\end{array}$ & $\begin{array}{l}62 \\
69 \\
\\
64 \\
62 \\
61\end{array}$ & $\begin{array}{r}147 \\
48 \\
203 \\
199 \\
\\
175 \\
212 \\
164 \\
164 \\
242\end{array}$ & $\begin{array}{c}\mathbf{0} \\
\mathbf{0} \\
\mathbf{0} \\
\mathbf{0} \\
\text { Trace } \\
0 \\
0 \\
0 \\
0 \\
\text { Trace }\end{array}$ & $\begin{array}{l}0 \\
0 \\
0 \\
0 \\
0 \\
0 \\
0 \\
0 \\
0\end{array}$ & $\begin{array}{l}0 \\
0 \\
0 \\
0 \\
0 \\
0 \\
0 \\
0\end{array}$ & $\begin{array}{l}0 \\
0 \\
+ \\
0 \\
+ \\
+ \\
+ \\
+ \\
+ \\
+\end{array}$ \\
\hline
\end{tabular}

* These cases appear in section A of this table. Under treatment, they became regulated. 
The bisulphite binding power of the blood in conditions other than vitamin $B_{1}$ deficiency

Diabetes mellitus. Table VI presents the data on: (A) "unregulated" diabetic patients and (B) "regulated" diabetic patients. Cases in the " unregulated" group showed elevated sugar and lowered carbon dioxide capacity of the blood, and sugar, acetone and diacetic acid in the urine. Cases in the " regulated" group at times had elevation of the blood sugar, but it was not accompanied by acidosis or ketosis.

Certain points emerge from a comparison of the two groups. In the unregulated patients there was an increase in the B.B.S. in the blood, which

TABLE VII

Cases with organic heart disease

(Arranged in order of severity of symptoms)

\begin{tabular}{|c|c|c|c|c|c|c|c|c|c|c|}
\hline \multirow{2}{*}{$\begin{array}{l}\text { Case } \\
\text { num- } \\
\text { ber }\end{array}$} & \multirow[b]{2}{*}{ Sex } & \multirow[b]{2}{*}{ Age } & \multirow{2}{*}{$\begin{array}{c}\text { Type of } \\
\text { heart } \\
\text { disease }\end{array}$} & \multirow{2}{*}{$\begin{array}{l}\text { Time of } \\
\text { test (day in } \\
\text { hospital) }\end{array}$} & \multirow{2}{*}{$\begin{array}{l}\text { B.B.S. } \\
\text { (as pyruvic } \\
\text { acid) }\end{array}$} & \multirow{2}{*}{$\underset{\substack{\text { Non- } \\
\text { protein } \\
\text { nitrogen }}}{ }$} & \multicolumn{3}{|c|}{ Urine analysis } & \multirow{2}{*}{ Course } \\
\hline & & & & & & & $\begin{array}{l}\text { Ace-- } \\
\text { tone }\end{array}$ & $\underset{\text { Di- Di- }}{\text { Dic }}$ & $\begin{array}{c}\text { Py- } \\
\text { ruvic }\end{array}$ & \\
\hline & & years & & & mgm. per $100 \mathrm{ml}$. & mgm. per $100 \mathrm{ml}$. & & & & \\
\hline
\end{tabular}

A. DECOMPENSATED CASES

\begin{tabular}{|c|c|c|c|c|c|c|c|c|c|c|}
\hline $\begin{array}{l}49 \\
50 \\
51 \\
52 \\
53 \\
54 \\
55 \\
56 \\
57 \\
58 \\
59 \\
60 \\
61 \\
62 \\
63 \\
64 \\
65 \\
66 \\
67\end{array}$ & $\begin{array}{l}\text { M. } \\
\text { M. } \\
\text { F. } \\
\text { M. } \\
\text { M. } \\
\text { M. } \\
\text { F. } \\
\text { M. } \\
\text { M. } \\
\text { M. } \\
\text { M. } \\
\text { F. } \\
\text { M. } \\
\text { M. } \\
\text { M. } \\
\text { M. } \\
\text { M. } \\
\text { F. } \\
\text { M. }\end{array}$ & $\begin{array}{l}65 \\
68 \\
53 \\
60 \\
59 \\
66 \\
42 \\
48 \\
57 \\
63 \\
55 \\
69 \\
43 \\
56 \\
56 \\
63 \\
54 \\
65 \\
52\end{array}$ & $\begin{array}{l}\text { C. T. } \\
\text { C. T. } \\
\text { R. } \\
\text { L. } \\
\text { R. T. } \\
\text { C. T. } \\
\text { R. C. } \\
\text { A. C. } \\
\text { H. A. } \\
\text { A. } \\
\text { H. } \\
\text { H. A. } \\
\text { R. } \\
\text { H. C. } \\
\text { R. } \\
\text { C. T. } \\
\text { C. } \\
\text { H. A. } \\
\text { C. }\end{array}$ & $\begin{array}{r}3 \\
5 \\
3 \\
49 \\
7 \\
5 \\
3 \\
28 \\
2 \\
2 \\
2 \\
3 \\
24 \\
50 \\
6 \\
2 \\
19 \\
18 \\
4\end{array}$ & $\begin{array}{l}6.6 \\
8.2 \\
7.9 \\
4.2 \\
6.6 \\
5.9 \\
5.6 \\
6.3 \\
7.5 \\
5.8 \\
5.6 \\
5.0 \\
7.2 \\
5.0 \\
7.5 \\
5.7 \\
4.2 \\
6.9 \\
6.5\end{array}$ & $\begin{array}{r}50 \\
211 \\
35 \\
40 \\
49 \\
48 \\
88 \\
39 \\
43 \\
43 \\
48 \\
32 \\
35 \\
27 \\
37 \\
87 \\
37 \\
80 \\
38\end{array}$ & $\begin{array}{l}0 \\
0 \\
0 \\
0 \\
0 \\
0\end{array}$ & $\begin{array}{l}0 \\
0\end{array}$ & 0 & $\begin{array}{l}\text { Died } \\
\text { Died } \\
\text { Died } \\
\text { Died } \\
\text { Died } \\
\text { Died } \\
\text { Died } \\
\text { Died } \\
\text { Improved } \\
\text { Improved } \\
\text { Improved } \\
\text { Improved } \\
\text { Improved } \\
\text { Improved } \\
\text { Improved } \\
\text { Improved } \\
\text { Improved } \\
\text { Improved } \\
\text { Improved }\end{array}$ \\
\hline
\end{tabular}

B. COMPENSATED CASES

\begin{tabular}{|c|c|c|c|c|c|c|c|c|c|c|}
\hline $\begin{array}{l}68 \\
69 \\
70 \\
71 \\
72 \\
73 \\
57^{*} \\
63^{*} \\
74 \\
75 \\
76 \\
77 \\
78 \\
79 \\
80 \\
81 \\
82 \\
67^{*} \\
83\end{array}$ & $\begin{array}{l}\text { F. } \\
\text { M. } \\
\text { F. } \\
\text { M. } \\
\text { M. } \\
\text { M. } \\
\mathbf{M} . \\
\mathbf{M} . \\
\mathbf{M} . \\
\mathbf{M} . \\
\mathbf{M} . \\
\mathbf{M} . \\
\mathbf{M} . \\
\mathbf{M} . \\
\mathbf{M} . \\
\mathbf{M} .\end{array}$ & $\begin{array}{l}36 \\
62 \\
71 \\
73 \\
40 \\
75 \\
57 \\
56 \\
36 \\
40 \\
67 \\
54 \\
40 \\
59 \\
68 \\
72 \\
77 \\
52 \\
19\end{array}$ & $\begin{array}{l}\text { R. } \\
\text { A. C. } \\
\text { H.A. } \\
\text { H. A. } \\
\text { R. } \\
\text { A. } \\
\text { H.A. } \\
\text { R. } \\
\text { C. } \\
\text { H. } \\
\text { A. } \\
\text { A. } \\
\text { R. } \\
\text { H. } \\
\text { H. A. } \\
\text { H. A. } \\
\text { A. } \\
\text { C. } \\
\text { R. }\end{array}$ & $\begin{array}{r}6 \\
21 \\
4 \\
5 \\
20 \\
4 \\
30 \\
30 \\
13 \\
27 \\
4 \\
12 \\
47 \\
3 \\
5 \\
2 \\
30 \\
30 \\
83\end{array}$ & $\begin{array}{l}3.4 \\
3.1 \\
5.7 \\
3.0 \\
4.0 \\
3.7 \\
4.5 \\
3.7 \\
3.3 \\
4.2 \\
3.2 \\
3.6 \\
5.5 \\
5.4 \\
3.4 \\
5.1 \\
5.3 \\
4.8 \\
4.7\end{array}$ & $\begin{array}{l}36 \\
37 \\
50 \\
62 \\
32 \\
39 \\
33 \\
38 \\
37 \\
42 \\
37 \\
20 \\
52 \\
51 \\
44 \\
44 \\
38\end{array}$ & $\begin{array}{l}0 \\
0 \\
0 \\
0 \\
0 \\
0 \\
0 \\
0 \\
0 \\
0 \\
0 \\
0 \\
0\end{array}$ & 0 & 0 & $\begin{array}{l}\text { Improved } \\
\text { Died } \\
\text { Improved } \\
\text { Improved } \\
\text { Improved } \\
\text { Improved } \\
\text { Improved } \\
\text { Improved } \\
\text { Improved } \\
\text { Improved } \\
\text { Improved } \\
\text { Improved } \\
\text { Improved } \\
\text { Improved } \\
\text { Improved } \\
\text { Improved } \\
\text { Improved } \\
\text { Improved }\end{array}$ \\
\hline
\end{tabular}

* These cases appear in section A of this table. Under therapy they became compensated.

$\dagger$ A. = Arteriosclerotic. C. = Coronary. H. = Hypertensive. R. = Rheumatic. L. = Luetic. C. T. = Coronary thrombosis. 
in some cases was extreme. The degree of elevation was related more directly to the "clinical" condition of the patient than to the acidosis as measured by the carbon dioxide capacity, or even to the ketosis as measured by ketone bodies in the urine. It bore no relation whatever to the level of the blood sugar. After treatment with insulin and fluids, the B.B.S. rapidly returned to normal and again closely paralleled the clinical appearance of the patient. The level of the B.B.S. in the blood is an accurate index of the severity of the metabolic disturbances and of the success of therapy in diabetic patients.

Tests for pyruvic acid were positive in the urines of several of the unregulated diabetic patients, a finding also recently observed by others (16). The rôle of pyruvic acid in the acidosis and in the elevation of the B.B.S. in diabetes awaits further observations.

Chronic organic heart disease. The association of cardiac disturbances with vitamin $B_{1}$ deficiency has been established in animals $(17,18)$. It is also generally recognized that cardiovascular dysfunctions occur in beriberi in the Orient $(19,20)$ and in vitamin " $B$ " deficiencies in the United States $(8,9,21)$. In order to determine what effect heart disease, with or without congestive failure, has on the B.B.S. in the blood, data were obtained on a control group of 35 patients with chronic organic heart disease without clinical evidence of vitamin deficiency. The data on this group are presented in Table VII : (A) "decompensated" patients with marked signs of congestive failure of the circulation; and (B) "compensated" patients with slight or no evidence of congestive failure. In the table the cases are arranged in order of clinical severity of decompensation, as determined by the amount of edema, venous distention, dyspnea, orthopnea and signs of pulmonary congestion that they manifested. It will be seen that in patients with organic heart disease there is a general correlation between the clinical severity of congestive failure and the elevation in the B.B.S. in the blood. The incidence of increased B.B.S. even in the decompensated group ( 52 per cent) was not so high as in patients with vitamin $B_{1}$ deficiency ( 74 per cent), nor was the degree of elevation so great (average B.B.S. $6.2 \mathrm{mgm}$. as compared with $12 \mathrm{mgm}$. per 100 ml.). Thus congestive failure alone, without de- monstrable vitamin deficiency, may be associated with increased B.B.S. in the blood. Congestive circulatory failure may therefore contribute to the elevation of the B.B.S. in certain cases of vitamin $\mathrm{B}_{1}$ deficiency with edema ("wet" beriberi). Following improvement under therapy with rest, digitalis and diuretics, the B.B.S. in the blood of cardiac patients returned to normal (Table VII-B).

Infections. The relationship of infection to vitamin deficiency and to the onset of clinical avitaminosis has often been commented on in the literature. The frequent occurrence of febrile episodes during the course of beriberi and pellagra and the aggravation of the symptoms of these diseases by infections have led many observers to accept the "infectious" theory of their etiology. Observations were therefore made on 17 patients with various infectious diseases in order to determine the relation of infection, and particularly of fever, to the B.B.S. in the blood. Table VIII presents the data on: (A) cases with febrile infections and (B) cases with infections which at the time of the measurements were afebrile. In none of the patients was there clinical evidence of vitamin deficiency. The cases are arranged in order of severity of the infection as judged from the height of the fever and the pulse rate, and from the degree of prostration of the patient.

There is a fairly close correlation between the elevation of the B.B.S. and the severity of the infection. That fever per se is not responsible for the increased B.B.S. is shown by Case 89 , in which there was normal B.B.S. but high fever due to severe tuberculosis. Dehydration with reduced kidney function, and ketosis as evidenced by acetonuria, undoubtedly play contributing rôles. It is also possible that anoxemia, such as occurs in lobar pneumonia, may be a factor in the metabolic disturbances which are associated with increased B.B.S. in the blood of some febrile patients. With recovery the B.B.S. in these patients returned to normal (Cases 84, 85, 86, 87). Afebrile infections were not associated with an increase in the B.B.S.

Nephritis. Five patients with glomerulonephritis, 4 with nephrosclerosis and 1 with nephrosis were studied. Among the patients with glomerulonephritis the nonprotein nitrogen varied from 35 mgm. per $100 \mathrm{ml}$. to $162 \mathrm{mgm}$. with no elevation 
TABLE VIII

Cases with infections

(Arranged in order of severity of symptoms)

\begin{tabular}{|c|c|c|c|c|c|c|c|c|c|}
\hline \multirow{2}{*}{$\begin{array}{c}\text { Case } \\
\text { num- } \\
\text { ber }\end{array}$} & \multirow{2}{*}{ Sex } & \multirow{2}{*}{ Age } & \multirow{2}{*}{ Diagnosis } & \multirow{2}{*}{$\begin{array}{l}\text { Time of } \\
\text { test (day in } \\
\text { hospital) }\end{array}$} & \multirow{2}{*}{$\begin{array}{c}\text { B.B.S. } \\
\text { (as pyruvic } \\
\text { acid) }\end{array}$} & \multirow{2}{*}{$\begin{array}{c}\text { Non- } \\
\text { protein } \\
\text { nitrogen }\end{array}$} & \multicolumn{3}{|c|}{ Urine analysis } \\
\hline & & & & & & & $\begin{array}{l}\text { Ace- } \\
\text { tone }\end{array}$ & $\begin{array}{l}\text { Di- } \\
\text { acetic }\end{array}$ & $\begin{array}{l}\text { Py- } \\
\text { ruvic }\end{array}$ \\
\hline & & years & & & mgm. per $100 \mathrm{ml}$. & mgm. per $100 \mathrm{ml}$. & & & \\
\hline
\end{tabular}

A. FEBRILE CASES

\begin{tabular}{l|l|l|l|r|r|r|r|r|r}
\hline 84 & F. & 14 & Lobar pneumonia & 4 & 8.0 & 48 & ++ & 0 & 0 \\
85 & M. & 40 & Lobar pneumonia & 2 & 8.1 & 43 & & & \\
86 & M. & 38 & Lobar pneumonia & 3 & 6.1 & 18 & ++ & \\
87 & M. & 46 & Lobar pneumonia & 5 & 9.2 & & & \\
88 & M. & 24 & Extensive tuberculosis & 51 & 6.4 & & \\
89 & F. & 28 & Pulmonary tuberculosis & 6 & 3.7 & & \\
90 & M. & 56 & Malaria & 8 & 3.9 & 32 & 0 & \\
91 & F. & 16 & Minimal tuberculosis & 7 & 4.3 & 37 & 0 & & \\
92 & M. & 16 & Acute respiratory infection & 2 & 6.4 & & Trace & & \\
\hline
\end{tabular}

B. AFEBRILE CASES

\begin{tabular}{|c|c|c|c|c|c|c|c|c|c|}
\hline $\begin{array}{c}93 \\
94 \\
95 \\
96 \\
97 \\
98 \\
99 \\
100 \\
84^{*} \\
85^{*} \\
86^{*} \\
87^{*}\end{array}$ & $\begin{array}{l}\text { M. } \\
\text { M. } \\
\text { M. } \\
\text { M. } \\
\text { M. } \\
\text { M. } \\
\text { M. } \\
\text { F. } \\
\text { M. } \\
\text { M. } \\
\text { M. }\end{array}$ & $\begin{array}{l}32 \\
28 \\
45 \\
24 \\
27 \\
25 \\
32 \\
32 \\
14 \\
40 \\
38 \\
46\end{array}$ & $\begin{array}{l}\text { Acute respiratory infection } \\
\text { Prostatitis; gonococcal arthritis } \\
\text { Meningitis } \\
\text { Primary syphilis } \\
\text { Primary syphilis } \\
\text { Primary syphilis } \\
\text { Primary syphilis } \\
\text { Rheumatic fever } \\
\text { Convalescent; lobar pneumonia } \\
\text { Convalescent; lobar pneumonia } \\
\text { Convalescent; lobar pneumonia } \\
\text { Convalescent; lobar pneumonia }\end{array}$ & $\begin{array}{r}5 \\
12 \\
30 \\
11 \\
14 \\
15 \\
9 \\
60 \\
8 \\
6 \\
7 \\
8\end{array}$ & $\begin{array}{l}3.9 \\
5.2 \\
4.4 \\
4.2 \\
3.7 \\
4.0 \\
5.2 \\
4.1 \\
3.9 \\
4.6 \\
4.0 \\
5.1\end{array}$ & $\begin{array}{l}36 \\
34 \\
25 \\
\\
25 \\
34 \\
33\end{array}$ & $\begin{array}{l}0 \\
0 \\
0 \\
0 \\
0 \\
0 \\
0\end{array}$ & $\begin{array}{l}\mathbf{0} \\
\mathbf{0} \\
\mathbf{0} \\
\mathbf{0} \\
\mathbf{0} \\
\mathbf{0} \\
\mathbf{0}\end{array}$ & $\begin{array}{l}0 \\
0 \\
0 \\
0 \\
0 \\
0 \\
0\end{array}$ \\
\hline
\end{tabular}

* These cases appear also in section $\mathrm{A}$ of this table.

of the bisulphite binding power. Two of the nephrosclerotic patients with nonprotein nitrogen of 96 and $78 \mathrm{mgm}$. per $100 \mathrm{ml}$. had values for B.B.S. in the blood of 6.1 and $7.8 \mathrm{mgm}$. per 100 ml., respectively. In the second case the carbon dioxide combining power was 47 volumes per cent. These two groups of patients show that there is no direct relationship between the nonprotein nitrogen and the bisulphite binding power of the blood. The patient with nephrosis showed the lowest B.B.S. recorded : $1.7 \mathrm{mgm}$. per $100 \mathrm{ml}$.

Jaundice and liver disease. Eight patients with various forms of jaundice and liver disease were studied. These included 5 cases of cirrhosis, 1 case each of catarrhal jaundice, of arsphenamine hepatitis and of cirrhosis complicated by diabetes mellitus with a blood sugar of $168 \mathrm{mgm}$. per 100 ml. The B.B.S. was not elevated in any of these patients.

Pregnancy. Six patients were studied in the third trimester of pregnancy. One patient had hypoproteinemia, 2 had essential hypertension and 3 had so-called "toxemia" of pregnancy. The carbon dioxide combining power varied between 50 and 57 volumes per cent. In no instance was there an elevated B.B.S.

Neoplasms. Five patients suffering from various forms of malignant disease, including 1 case of Hodgkin's disease, were observed. In no case was the B.B.S. elevated.

Miscellaneous. No elevation of the B.B.S. was found in 2 cases of senility with arteriosclerosis or in 1 case each of secondary anemia, pernicious anemia, hypoproteinemia with malnutrition, and hyperthyroidism.

One patient suffering from epilepsy when placed on a therapeutic ketogenic diet showed an increase in B.B.S. to $21 \mathrm{mgm}$. per $100 \mathrm{ml}$. In this patient elevation of the B.B.S. occurred without any lowering of the carbon dioxide capacity 
of the blood. One patient with pernicious vomiting and acidosis showed an elevation of the B.B.S. to $13 \mathrm{mgm}$. per $100 \mathrm{ml}$.

Cases with multiple diseases. There were 7 cases in which a single diagnosis could not be made. In 5 of these the B.B.S. was elevated above normal limits. They were cases in which any one of the presenting diseases may be associated with an elevation of the B.B.S. The data on these patients are given in Table IX.
The relationship of the B.B.S. to certain other constituents of the blood

Glucose. Under the conditions of the method outlined above, bisulphite is not bound by glucose. This was established by the following experimental considerations: (1) The addition of glucose to blood in vitro caused no change in the bisulphite binding power. (2) The intravenous injection of $100 \mathrm{cc}$. of 50 per cent glucose solution caused no change in the bisulphite binding

TABLE IX

Cases with multiple diseases

\begin{tabular}{|c|c|c|c|c|c|c|c|c|c|}
\hline \multirow{2}{*}{$\begin{array}{c}\text { Case } \\
\text { num- } \\
\text { ber }\end{array}$} & \multirow{2}{*}{ Sex } & \multirow{2}{*}{ Age } & \multirow{2}{*}{ Diagnosis } & \multirow{2}{*}{$\begin{array}{l}\text { Time of } \\
\text { test (day in } \\
\text { hospital) }\end{array}$} & \multirow{2}{*}{$\begin{array}{l}\text { B.B.S. } \\
\text { (as pyruvic } \\
\text { acid) }\end{array}$} & \multirow{2}{*}{$\begin{array}{c}\text { Non- } \\
\text { protein } \\
\text { nitrogen }\end{array}$} & \multicolumn{2}{|c|}{ Urine analysis } & \multirow{2}{*}{ Additional findings } \\
\hline & & & & & & & $\begin{array}{l}\text { Ace- } \\
\text { tone }\end{array}$ & $\begin{array}{l}\text { Di- } \\
\text { acetic }\end{array}$ & \\
\hline & & years & & & $\begin{array}{l}\text { mgm. per } \\
100 \mathrm{ml} \text {. }\end{array}$ & $\begin{array}{l}\text { mgm. per } \\
100 \text { mb. }\end{array}$ & & & \\
\hline 101 & M. & 46 & $\begin{array}{l}\text { Chronic alcoholic cirrhosis; } \\
\text { acute hepatitis; fever }\end{array}$ & 3 & 9.5 & 24 & 0 & $\mathbf{0}$ & \\
\hline 102 & F. & 22 & $\begin{array}{l}\text { Congenital syphilis; preg- } \\
\text { nancy; pyelitis; jaundice; }\end{array}$ & 30 & 2.6 & 28 & $\mathbf{0}$ & & \\
\hline 103 & F. & 63 & $\begin{array}{l}\text { Arteriosclerosis; diabetes; } \\
\text { nephritis; heart failure }\end{array}$ & 23 & 11.5 & 78 & $\mathbf{0}$ & & Blood sugar 258 \\
\hline 104 & F. & 28 & $\begin{array}{l}\text { Pancreatitis; nephritis; } \\
\text { myocarditis; vomiting }\end{array}$ & 38 & 8.5 & 42 & & & Carbon dioxide 29 \\
\hline 105 & M. & 60 & $\begin{array}{l}\text { Bichloride poisoning; } \\
\text { uremia }\end{array}$ & 14 & 7.4 & 176 & $\mathbf{0}$ & $\mathbf{0}$ & \\
\hline 106 & M. & 55 & $\begin{array}{l}\text { Hodgkin's disease; coro- } \\
\text { nary heart disease; }\end{array}$ & 11 & 8.4 & 56 & & & \\
\hline 107 & M. & 26 & $\begin{array}{l}\text { chronic nephritis } \\
\text { Chronic colitis; hypopro- } \\
\text { teinemia }\end{array}$ & 3 & 3.6 & 26 & 0 & 0 & Carbon dioxide $\mathbf{5 0}$ \\
\hline
\end{tabular}

Diseases associated with detreased B.B.S. in the blood

Eighteen patients showed B.B.S. ranging from 1.9 to $3.5 \mathrm{mgm}$. per $100 \mathrm{ml}$. Serum protein analyses were made on 8 of these patients. All 8 had hypoproteinemia. Low B.B.S. was found in 5 cases with heart disease of arteriosclerotic or hypertensive origin, in 4 cases of pregnancy, in 2 cases of cirrhosis, in 2 cases of nutritional deficiency, in 1 patient with chronic passive congestion of the circulation due to tricuspid stenosis, and in 1 case each of nephrosis, pernicious anemia, and severe secondary anemia. The most common finding associated with a lowering of the B.B.S. in this study was the reduction in the serum proteins. power, although it greatly increased the blood sugar. (3) In diabetic patients with elevated blood sugar but without acidosis the bisulphite binding power of the blood was not increased. There was no relationship between the B.B.S. and the glucose in the blood.

Nonprotein nitrogen. Patients suffering from glomerulonephritis with increases in the nonprotein nitrogen showed no increase in the B.B.S. In clinical " uremia," however, an increase in the nonprotein nitrogen was often accompanied by an increase in the B.B.S. With amelioration of the uremic condition the elevated B.B.S. returned to normal.

Carbon dioxide capacity of the blood. There appears to be no direct relationship between the B.B.S. and the carbon dioxide capacity of the 
blood. A simple lowering of the carbon dioxide capacity in several patients by means of ammonium chloride therapy even to the point of clinical acidosis produced no change in the B.B.S. There is, however, a distinct relationship between the B.B.S. and certain underlying factors which may result in a lowering of the carbon dioxide capacity. Patients with diabetic acidosis, for example, in whom the decreased carbon dioxide capacity was due primarily to ketosis showed exceedingly high B.B.S. in the blood. On the other hand, a patient on a ketogenic régime for epilepsy had a high B.B.S. but a normal carbon dioxide capacity.

Pyruvic acid. The relationship of the B.B.S. to pyruvic acid requires further investigation. As judged from the amount of this material found in the urine and from preliminary work on direct measurement of the substance in the blood, pyruvic acid alone cannot account for the increased B.B.S. in the blood of patients with vitamin $B_{1}$ deficiency or the other diseases observed with an elevation of the B.B.S.

Drugs. Many of the patients under observation were of necessity given various sedative drugs. Frequently, the medication was administered on admission to the hospital. This was particularly true of patients with acute or chronic alcoholism. Chief interest centered in such drugs as chloral hydrate and paraldehyde, which have free carbonyl groups. In 3 instances it was found that the administration of large doses of these drugs was followed by a slight rise in the B.B.S. Several patients, however, after equally large amounts of the same sedatives showed normal B.B.S. Drugs other than chloral hydrate and paraldehyde showed no effect on the B.B.S.

\section{The B.B.S. and rest}

In some cases the routine treatment and diet alone, with no specific therapy, reduced the B.B.S. in the blood. This was true not only in the vitamin $B_{1}$ deficient group but also in all types of cases in which an increase in B.B.S. occurred. The lowering of the B.B.S. in these cases was ascribed primarily to the effects of bed rest and decrease in total metabolism, but undoubtedly the administration of fluids and probably other factors played a rôle. For this reason the length of time after admission that the test was done often had a bearing on the height of the B.B.S.

\section{DISCUSSION}

The observations presented indicate that elevation of B.B.S. in the blood is not specific in vitamin $B_{1}$ deficiency, since it occurs in other diseases, such as diabetes mellitus, certain infectious diseases and severe congestive failure of the circulation caused by organic heart disease. In these diseases the total B.B.S. cannot always be accounted for by the presence of acetone and diacetic acid. In certain cases of vitamin $\mathrm{B}_{1}$ deficiency high B.B.S. in the blood was observed without acetone, diacetic or pyruvic acid in the urine, suggesting that other carbonyl compounds had accumulated in the blood. It is of significance that there were instances both of polyneuritis and of cardiac insufficiency of nutritional origin with low vitamin $B_{1}$ intake in which the B.B.S. was normal. Thus a simple correlation was not found between the level of B.B.S., on the one hand, and the severity of the nutritional polyneuritis and cardiovascular dysfunction, on the other. These findings are not entirely in agreement with those of Platt and $\mathrm{Lu}$, but they are in accord with the studies of de Jong (22) on pigeons with vitamin $B_{1}$ deficiency. De Jong did not find a simple correlation between the manifestations of vitamin $B_{1}$ deficiency and the B.B.S. in the blood. Polyneuritis of pigeons developed before the elevation of the B.B.S., and in one group of animals the disappearance of symptoms preceded the lowering of the B.B.S. Furthermore, symptoms of chronic polyneuritis were not accompanied by a rise in the B.B.S. in the blood.

Vitamin $B_{1}$ deficiency in certain of the patients studied was associated with disturbance both of the fat and of the carbohydrate metabolism. This was shown not only by the increase in carbonyl substances other than acetone and diacetic acid, but also by hyperglycemia, which disappeared following treatment.

\section{SUMMARY AND CONCLUSIONS}

1. Measurement of the B.B.S. in the blood gives a quantitative index of metabolic disturbances which result in an accumulation of carbonyl 
compounds. It is not possible, however, to differentiate the various carbonyl metabolites by this procedure.

2. Observations are reported on the relation of B.B.S. to other chemical constituents of the blood, such as glucose, nonprotein nitrogen and carbon dioxide capacity.

3. Since an increase in the B.B.S. occurs in a variety of diseases, its use as a diagnostic test of any one disease is not feasible.

4. The B.B.S. in the blood is increased in vitamin $B_{1}$ deficiencies, in unregulated diabetes mellitus, in febrile infections, in severe congestive circulatory failure due to organic heart disease, and in certain less common diseases.

5. In diabetes mellitus, incomplete fat metabolites, such as acetone and diacetic acid, contribute a portion to the increase in the B.B.S. Pyruvic acid is present in the urine of some patients with unregulated diabetes. The level of the B.B.S. is an accurate index of the degree of ketosis and of the clinical severity in this disease.

6. The elevation of the B.B.S. in certain cases of vitamin $B_{1}$ deficiency cannot be entirely explained by the presence of acetone, of diacetic acid or of pyruvic acid. The effect of vitamin $B_{1}$ in lowering the B.B.S. in such cases suggests an important oxidative rôle of this vitamin in metabolism.

7. In alcoholic polyneuritis and heart failure (" alcoholic beriberi") alcohol per se is not responsible for elevation of the B.B.S.

8. In 4 patients with vitamin $B_{1}$ deficiency hyperglycemia was observed which disappeared under treatment.

This investigation was carried out with the technical assistance of Miss Jane W. Bryant, A.B., and Miss Sophia M. Simmons, S.B.

\section{BIBLIOGRAPHY}

1. Peters, R. A., Rydin, H., and Thompson, R. H. S., Brain respiration, a chain of reactions, as revealed by experiments upon the catatorulin effect. Biochem. J., 1935, 29, 53.

2. Peters, $R$. A., The biochemical lesion in vitamin $B_{2}$ deficiency. Application of modern biochemical analysis in its diagnosis. Lancet, 1936, 1, 1161.
3. Thompson, R. H. S., and Johnson, R. E., Blood pyruvate in vitamin $B_{1}$ deficiency. Biochem. J., 1935, 29, 694.

4. Johnson, R. E., The isolation of pyruvic acid from the blood of vitamin $\mathrm{B}_{1}$-deficient pigeons. Biochem. J., 1936, 30, 31.

5. Platt, B. S., and Lu, G. D., Intermediate carbohydrate metabolism in vitamin $B_{1}$ deficiency in man. Proc. Chinese Physiol. Soc., Third General Conference, Chinese M. A., 1935, p. 16.

6. Sherman, W. C., and Elvehjem, C. A., The effect of polyneuritis in chicks upon the in vivo rate of removal of pyruvate injected intravenously. J. Nutrition, 1936, 12, 321.

7. Platt, B. S., and Lu, G. D., Chemical and clinical findings in beri-beri with special reference to vitamin $B_{1}$ deficiency. Quart. J. Med., 1936, n.s. 5, 355.

8. Weiss, S., and Wilkins, R. W., The nature of the cardiovascular disturbances in vitamin deficiency states. Tr. A. Am. Physicians, 1936, 51, 341.

9. Weiss, S., and Wilkins, R. W., The nature of the cardiovascular disturbances in nutritional deficiency states (beriberi). Ann. Int. Med., 1937, 11, 104.

10. Clift, F. P., and Cook, R. P., A method of determination of some biologically important aldehydes and ketones, with special reference to pyruvic acid and methylglyoxal. Biochem. J., 1932, 26, 1788.

11. Folin, Otto, Laboratory Manual of Biological Chemistry. Appleton Century Co., New York, 1934, 5th ed.

12. Howe, P. E., The determination of proteins in blood. A micro method. J. Biol. Chem., 1921, 49, 109.

13. Peters, J. P., and Van Slyke, D. D., Quantitative Clinical Chemistry. Vol. II. Methods. Williams and Wilkins Co., Baltimore, 1932, p. 691.

14. Ibid., p. 283.

15. Johnson, R. E., Personal communication.

16. Suñer, A. Pi, and Farrán, M., Nachweis von Brenztraubensäure im Urin. Biochem. Ztschr., 1936, 287, 113.

17. Drury, A. N., Harris, L. J., and Maudsley, C., Vitamin B deficiency in the rat. Bradycardia as a distinctive feature. Biochem. J., 1930, 24, 1632.

18. Zoll, P. M., and Weiss, S., Electrocardiographic changes in rats deficient in vitamin $B_{1}$. Proc. Soc. Exper. Biol. and Med., 1936, 35, 259.

19. Keefer, C. S., The beriberi heart. Arch. Int. Med., $1930,45,1$.

20. Wenckebach, K. F., Das Beriberi Herz. Julius Springer, Berlin and Vienna, 1934.

21. Feil, H., A clinical study of the electrocardiogram and of the phases of cardiac systole in pellagra. Am. Heart J., 1936, 11, 173.

22. De Jong, S., Bisulphite binding capacity of the blood of pigeons with $B_{1}$ deficiency. Arch. néerl. de physiol., 1936, 21, 465. 